\title{
Stability of underground mine workings due to surface blasting
}

\author{
PK Singh \\ Director, CSIR - Central Institute of Mining and Fuel Research \\ Dhanbad, India \\ pradeep.cimfr@gmail.com
}

\begin{abstract}
Blasting in the mining industry is being transformed, and can no longer be treated as an art or a practice purely dependent upon experiences of individuals. Examples of key drivers that have demanded consistent and more accurate blast results are initiatives to control pit-wall damage to help mine operators for steeper pit slope angles, to control damage to adjoining underground mine opening due to open-pit mining. Such situation exists at Rampura Agucha open-pit lead zinc mine which is producing $5.7 \mathrm{Mt} / \mathrm{a}$ of ore and has started its underground part which is slated to produce initially 2-2.4 Mt/a and 4.5 Mt/a in near future. The open-pit mine is currently working at $370 \mathrm{~m}$ depth and is designed to reach $400 \mathrm{~m}$ deep. The underground operations have been commenced successfully maintaining $50 \mathrm{~m}$ parting from the planned ultimate level of the open-pit mine.
\end{abstract}

Presently, open-pit and underground mines are being operated simultaneously. The present average depth of underground working lies between 370 and $410 \mathrm{~m}$ below the surface level. Sometimes explosives up to $95,978 \mathrm{~kg}$ are being detonated in a blast round in open-pit mine for speedy removal of overburden. These blasts are often apprehended as a danger to the safety and stability of underground openings. It was decided to document the impact of open-pit blasting in the openings of underground workings, so that preventive measures may be taken for the safety and long term stability of the underground mine. The impact of 86 open-pit blasts has been documented in the underground openings and 258 blast vibration data has been recorded. The vibrations were recorded simultaneously in the roof, side walls and at floor levels. The highest levels of vibrations were recorded in the roof and the lowest levels at the corresponding floor levels. The pillars experienced lower level of vibrations than those of the roof. Blast designs were optimised at open-pit mine to control vibration in view of long term safety and stability of the underground openings. The underground development face blasts were also optimised for the safety and stability of underground workings. Vibrations generated due to detonation of explosives with shock tubes and electronic delay detonators have been recorded in underground openings for comparative assessment. Ground vibration recorded at roof, pillar and floor were analysed separately and threshold value of the vibration for the safety of underground workings has been determined based on the Rock Mass Rating (RMR) of the roof rock and accordingly blast designs have been optimised which helped in exploitation of precious minerals from openpit as well as from underground mines simultaneously.

Keywords: blasting; vibrations; Rock Mass Rating

\section{INTRODUCTION}

It is known fact that the safety and stability of underground mine openings, sidewalls/pillars, water dams, etc. in close proximity to operating open-pit mines are often endangered from blast induced vibrations. Mine operators attempt to get better fragmentation of rock even if a blast requires high consumption of explosives per tonne of the mineral produced, as improved fragmentation reduces the cost of loading, conveying and crushing of minerals. These blasts generate seismic disturbances, which in turn may damage the support system and may potentially affect the stability of roof and sidewalls/pillars of galleries in underground mines. It may induce opening of cracks in the strata rendering them unstable. Also, there is a possibility of spalling in adjoining workings.

The seismic disturbances induced by blasting will depend on the total explosive energy released during blasting and the nearness of the underground workings to operating open-pit mine. There are several examples of underground mines which operate in close proximity to an operating open-pit mine. In such operations, the blast induced ground vibrations generated due to open-pit blasting may be a potential cause for the instability of adjoining underground mine workings and can be hazardous. Such situation exists at RampuraAgucha mine where open-pit and underground mines are being operated with a parting of $60 \mathrm{~m}$ and it is planned to have an ultimate parting of only $50 \mathrm{~m}$. The blasts are being conducted on different benches of hanging wall, foot wall and ore benches of open-pit mine.

Explosive weight per delay, travel distance (depth) and transmitting media properties (elastic modulus and density) have significant impact on vibration characteristics generated at the underground structures due to nearby surface blasting $[27,26]$ reported minor damage in the form of localized thin spalls and collapse of previously fractured coal ribs resulted from blast having an associated PPV more than $50 \mathrm{~mm} / \mathrm{s}$. No other major damage or changes in the mine condition (roof bolts and convergence) were noted. [12] reported no roof failures even at roof vibrations of 445 $\mathrm{mm} / \mathrm{s}$, and only a few loose stones at $127 \mathrm{~mm} / \mathrm{s}$. [16] concluded that the theoretical maximum vibration limit for underground coal roadways is approximately $250 \mathrm{~mm} / \mathrm{s}$. He also addressed the question concerning the effects of the repetitive action of blasting and its impact on the rock strata behavior and observed that the repetitive blasting does not 
have any significant impact on the roof stability of the adjacent underground colliery. [13] reported that damage to underground coal mine openings in the form of small roof falls or floor heave may occur when the PPV lies in the range of $50-100 \mathrm{~mm} / \mathrm{s}$, and large roof falls at $100-200 \mathrm{~mm} / \mathrm{s}$. The allowable limits of vibration for various types of surface and underground structures have been reported by various researchers $[27,6 \& 28]$. In the case of primary mine openings (service life up to ten years), pit bottom, main cross entries and drifts, the allowable values reported were $120 \mathrm{~mm} / \mathrm{s}$ for one-time blasting and $60 \mathrm{~mm} / \mathrm{s}$ for repeated blasting. For secondary mine openings (service life up to three years), haulage break-through and drifts, the allowable values suggested were $240 \mathrm{~mm} / \mathrm{s}$ for repeated blasting and $480 \mathrm{~mm} / \mathrm{s}$ for one-time blasting. [37] reported no collapse in water filled workings at $670 \mathrm{~mm} / \mathrm{s}$. [7] concluded that allowable PPV (typically $50 \mathrm{~mm} / \mathrm{s}$ ) to avert damage to surface structures is much lower than that at which damage begins to become a concern in underground mines.

They reported that PPV of as much as $110 \mathrm{~mm} / \mathrm{s}$ produced only minor damage and serious extensive damage resulted when PPV reached $390 \mathrm{~mm} / \mathrm{s}$ [25] documented the mechanics of spalling in rock due to input wave produced by explosive action or high-velocity impact and the material behaviour. [19] observed no damage in underground coal mine workings at $58 \mathrm{~mm} / \mathrm{s}$.

That peak particle velocity [32] of $48 \mathrm{~mm} / \mathrm{s}$ didn't cause any damage to the underground workings. [1] studied overbreak and crack extensions from blasting which have the potential to influence long term stability of excavations. They found that most distant effect on the extension of existing cracks extended to $4.5 \mathrm{~m}$ at the most. The peak particle velocity at this distance ranged between 300 and $398 \mathrm{~mm} / \mathrm{s}$. On the other hand, with poor quality rock (RMR $=49$ ), which had been loosened by previous open-pit blast vibrations, minor visible damage at peak particle velocity of $46 \mathrm{~mm} / \mathrm{s}$ and major damage at a peak particle velocity of $379 \mathrm{~mm} / \mathrm{s}$ were observed. [39] have observed development of cracks in the coal roof at peak particle velocity of 297 $\mathrm{mm} / \mathrm{s}$ but spalling of coal chips from pillars and roof started at a level of $125 \mathrm{~mm} / \mathrm{s}$. [38] suggested that peak particle velocity of $175 \mathrm{~mm} / \mathrm{s}$ did not cause any damage to underground opening when very good quality rock $(\mathrm{RMR}=85)$ was encountered.[17], set a conservative criterion of targeted maximum PPV of $50 \mathrm{~mm} / \mathrm{s}$ for the safety of coal underground heading.

They further stated that this conservative value of PPV was decided after investigations indicated a possible limit of $250 \mathrm{~mm} / \mathrm{s}$. [27] conducted an extensive study in six coal mines in India and established the threshold value of vibration (PPV) for different RMR of roof rocks in underground workings for safe and efficient exploitation of coal from opencast and underground mines simultaneously.

Established guidelines are based on results of 202 blasts conducted in open-pit mines and 622 blast vibration signatures were recorded in corresponding underground openings. Singh [27] suggested that PPV of $100 \mathrm{~mm} / \mathrm{s}$ will not cause damage to the underground coal mine workings having RMR of 50 .

The formation of excavation damaged zone around tunnel under geo-stress environment involves a coupled damage evolution process, whose main mechanism is growth of cracks owing to unloading and stress redistribution apart from blasting [41]. Loading stiffness and stress distribution in the surrounding rock mass, resulting in both stable and unstable shear failures along discontinuities as the excavation proceeds, influence the stability of underground workings apart from ground vibrations generated due to blasting [8].

\section{DESCRIPTION OF THE EXPERIMENTAL SITE}

Rampura Aguchamine is located at $225 \mathrm{~km}$ northnortheast of Udaipur, Rajasthanand is the largest and richest Lead Zinc deposit in India containing ore reserves of 107.33 Mt with grade of $13.9 \%$ zinc and 2\% lead. The Rampura Agucha mixed sulphide deposit is a massive lens shaped ore body with a NE-SW strike length of $1500 \mathrm{~m}$ and a width varying from a few metres in the NE direction widening to as much as $120 \mathrm{~m}$ in the central to $\mathrm{SW}$ section. At present Rampura Aguchaopen-pit mine is producing 5.7Mt/a of ore and with present system of the mining method (open-pit) the mine will be operative up to depth of $421 \mathrm{~m}$ below the surface. The present depth of open pit mine is $326 \mathrm{~m}$.

Rampura Agucha is a stratiform, sediment-hosted Lead Zinc deposit, occurs in Pre-Cambrian Banded Gneissic complex and forms a part of Mangalwar complex of Bhilwara geological cycle (3.2-2.5 billion years) of Archean age and comprising of magmatites, gneisses, graphite mica schist, pegmatite and impure marble. The rocks have been subjected to polyphase deformations and high-grade metamorphism. The geological evolution of southeastern Rajasthan occurred during three major orogenic cycles represented by the terrains named Banded Gneissic Complex (BGC), Aravalli Supergroup and Delhi Supergroup [9].

The conceptual underground study has been carried out and deposit has potential to carry out concurrent mining in open-pit as well as in underground. It has been planned to approach to the deposit below ultimate pit by a decline and a shaft from surface.Decline development (1 in 7 ramp gradients) of size $5.3 \mathrm{~m}(\mathrm{H}) \times 5.6 \mathrm{~m}(\mathrm{~W})$, i.e. $29.68 \mathrm{~m}^{2}$ cross section areas has been taken. The access to underground mine workings from surface is though a single decline that branches into north and south decline for providing access to lower levels below $60 \mathrm{~m}$ high crown pillar from -5 to $65 \mathrm{~m}$ RL extending to full strike length of the ore body. To access the ore, footwall drive and crosscuts are developed by drill \& blast method at each of the drill (+13 m RL) and extraction level (-5 m RL).

Longhole production drilling (76-89mm down holes) is carried out from $+13 \mathrm{~m}$ RL to $-5 \mathrm{~m}$ RL. Ore extraction is done at $-5 \mathrm{~m}$ RL. The slot raise is being developed by drop raising method by drilling holes and then the slot raise is widened up to the full width of the stope. Against the free face, so developed by the slot, the ring blasting is being 
carried out in retreating pattern. All drives, crosscuts and junctions are being systematically supported using rock bolts, cable bolts, wire mesh,shotcreting etc. The mined out stopes are being filled with cemented rock fill (CRF). The mechanical properties of rocks are given in Table I.

The ore body is massive and single lens having a strike length of about $1400 \mathrm{~m}$ at $18 \mathrm{~m} \mathrm{RL}$ and the average dip of the ore body is 55 degree.

It is being proposed that the stopping method shall be sublevel open stopes with paste filling. In this method, 200 $\mathrm{m}$ vertical ore block is being considered and 8 sublevels at $25 \mathrm{~m}$ interval shall be developed. Each sublevels stope will be developed by driving, access drive to decline, drill drive and cross cuts. Stopping will be done in a sequential manner so that the immediately after the extraction the void stope shall be filled with paste and other stopes are ready for production.

The isometric view of the Rampura Agucha open-pit and underground mine is presented in figure1.Support system such as wire mesh, roof bolts, shot creating etc. are being used in the mine and is shown in Fig.2.

TABLE I. PHYSICO-MECHANICAL PROPERTIES OF ROCKS AT RAMPURA AGUCHA MINE

\begin{tabular}{|c|c|c|c|c|c|}
\hline $\begin{array}{c}\text { Rock } \\
\text { Type }\end{array}$ & $\begin{array}{c}\text { Com } \\
\text { pressi } \\
\text { ve } \\
\text { Stren } \\
\text { gth } \\
\text { (MPa } \\
\text { ) }\end{array}$ & $\begin{array}{c}\text { Young' } \\
\text { s } \\
\text { Modulu } \\
\text { s (GPa) }\end{array}$ & $\begin{array}{c}\text { Poisso } \\
\text { n's } \\
\text { Ratio }\end{array}$ & $\begin{array}{c}\text { Tensile } \\
\text { Strength } \\
\text { (MPa) }\end{array}$ & BRMR \\
\hline AMP & 74 & 18.6 & 0.13 & 8.7 & 62 \\
\hline GBG & 59 & 14.8 & 0.10 & 7.6 & 60 \\
\hline GBSG & 44 & 12.3 & 0.17 & 6.8 & 50 \\
\hline ORE & 68 & 23.2 & 0.07 & 7.9 & 62 \\
\hline PEG & 76 & 13.2 & 0.05 & 6.5 & 72 \\
\hline
\end{tabular}

*AMP - Amphibolite; GBG - Garnet biotite gneiss; GBSG - Garnet biotite-silimanite gneiss; PEG - Pegmatite

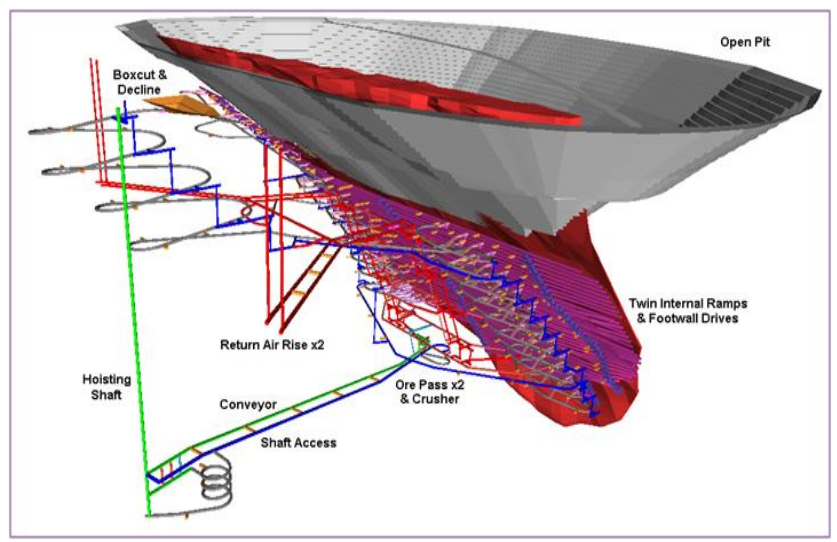

Fig. 1. Isometric view of the Rampura Agucha open-pit and underground mine

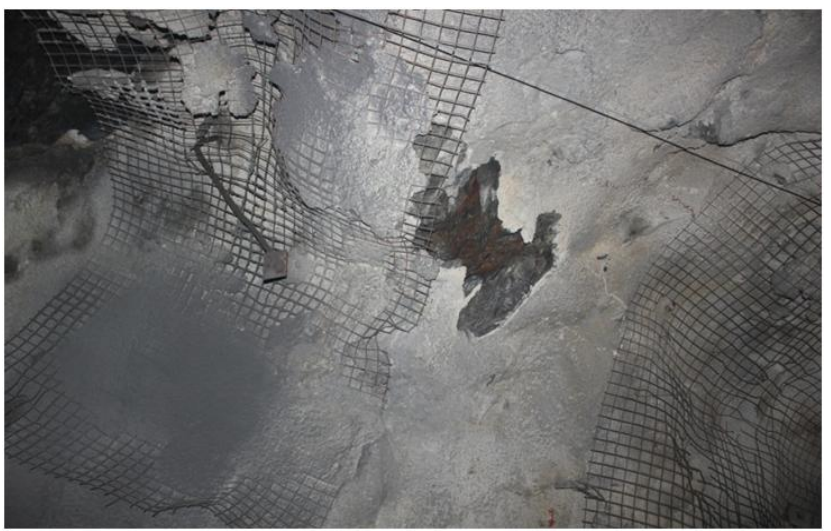

Fig. 2. Different support systems used in Rampura Agucha underground mine for reinforcement of roof rock

\section{BLASTING DETAILS AT OPEN-PIT MINE}

Study was carried out with the existing blast designs practiced in the mine as well as with modified blast design to achieve the objective of the study. The open-pit mine works with shovel-dumper combination deploying large sized heavy earth moving machines like $34 \mathrm{~m}^{3}$ shovels and 220 tone trucks navigation with Truck Dispatch System (TDS). The open-pit operations will be continued with shovel dumper combination delivering ore production of 5.7 $\mathrm{Mt} / \mathrm{a}$ andis also being supplemented by underground workings. The diameter of the blast holesare $115 \mathrm{~mm}$ and $165 \mathrm{~mm}$.The initiation system includes detonating cord, shock tubes and electronic delay detonators.

The vertical distance from open-pit blasting site to underground monitoring points varied from $60 \mathrm{~m}$ to $758 \mathrm{~m}$ whereas radial distance varied from $97 \mathrm{~m}$ to $2171 \mathrm{~m}$. The explosive charge weight per delay fired in a blasting round varied widely ( $30 \mathrm{~kg}$ to $825 \mathrm{~kg}$ ) depending on the size of the blast. Similarly, the total explosive weight in a blast round varied from $79 \mathrm{~kg}$ to $95978 \mathrm{~kg}$. A few blast designsexperimented at open-pit mine are presented in Fig. 3 \& Fig. 4. Two hundred and fifty-eight blast induced ground vibration data were recorded from 86 open-pit blasts.

\section{A. Monitoring of Ground Vibration due to open-pit Blasting}

Arrangements were made to mount the transducers of seismographs in the roof and side walls along and across the board in the selected area of underground openings. Seismographs having eight as well as four channels provided with two/one tri-axial transducer(s) for monitoring of vibration (in $\mathrm{mm} / \mathrm{s}$ ) were used.The blast vibrations were recorded at standard samples rate of 1024 samples per second for the blast conducted at more than $200 \mathrm{~m}$ whereas sample rate of 4096 per second were used when blasts were conducted in close proximity to the monitoring point. The locations in the roof were at the junctions as wellas in between the two junctions of galleries; in the side wallsthey were 1.2-1.6 m below the roof and at depths of 0.5-0.6 m inside pillars. Monitoring of vibrations was carried out simultaneously at different locations of underground 


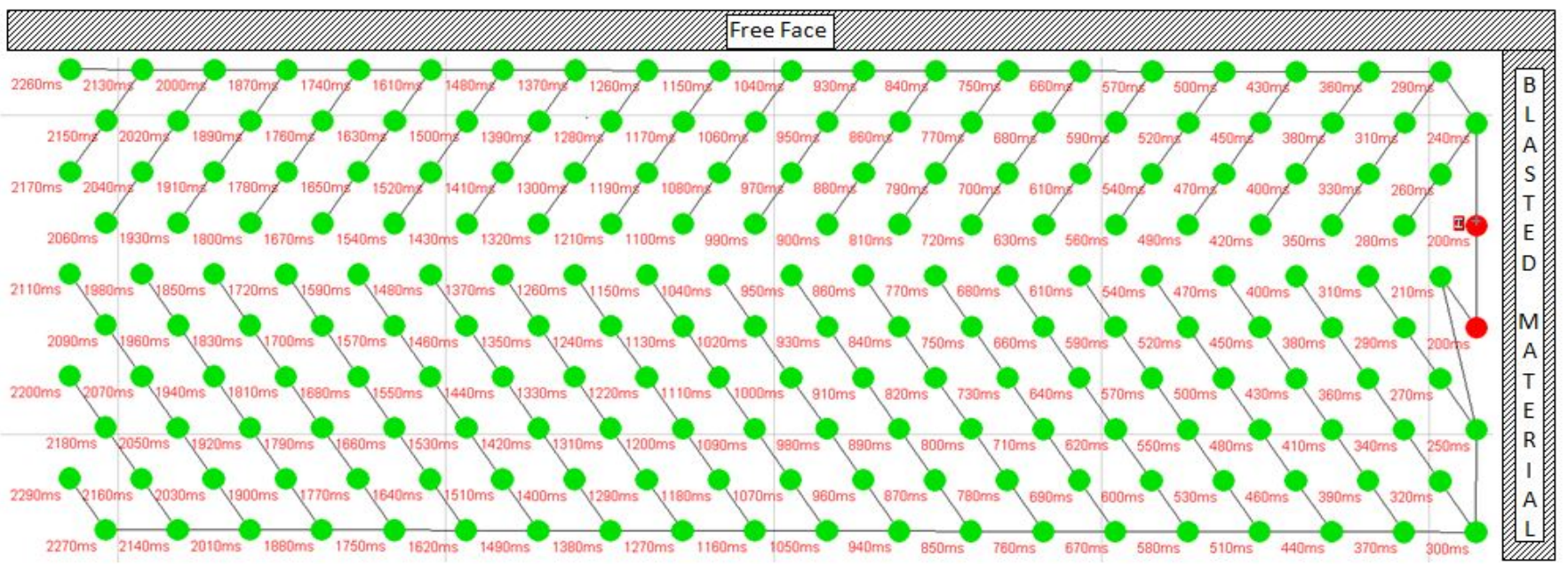

Fig. 3.Experimented blast design for Hangwall bench at RampuraAguchaopen-pit mine

\section{FREEFACE}

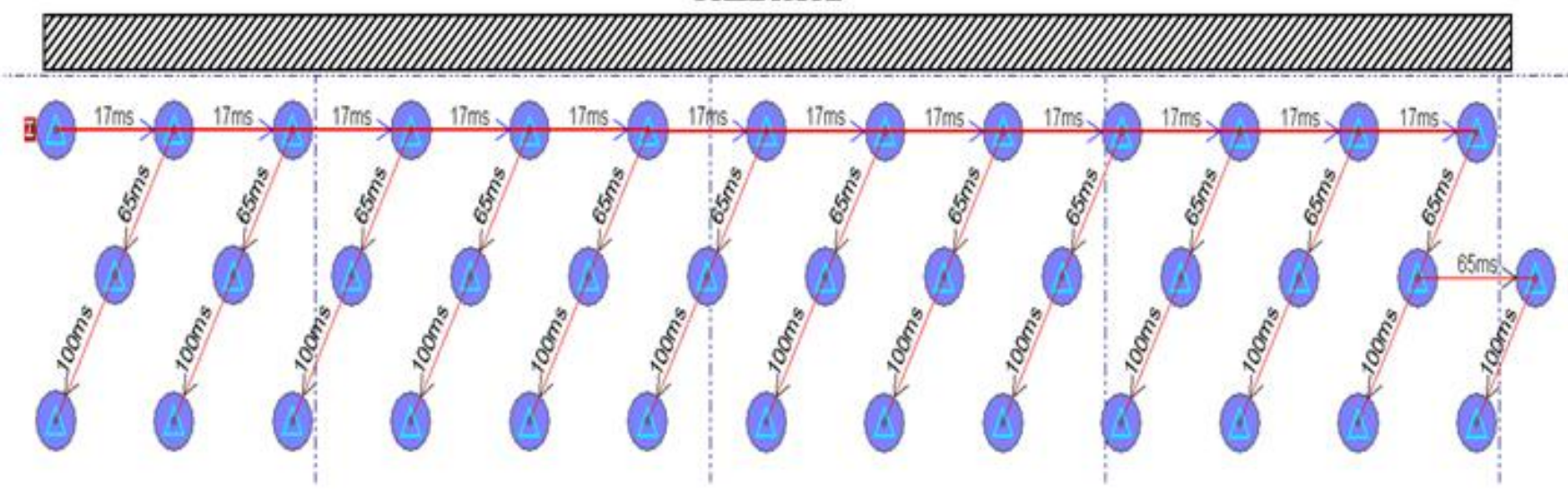

Fig. 4.Experimented blast design for Ore bench at RampuraAguchaopen-pit mine.

workings by deploying 2 to 4 seismographs. Figure 5 shows the transducer of seismograph installed in the roof with the help of grouted brass rodand notches were prepared in the sidewallto record blast induced ground vibrations. The recorded peak particle velocities varied widely depending upon the distance to the monitoring locations from the blasting face and the number of explosives detonated in the blast round. It varied between 0.439 and $24.7 \mathrm{~mm} / \mathrm{s}$ in the roof, 0.46 to $35.1 \mathrm{~mm} / \mathrm{s}$ in the sidewalls/pillars and 0.42 to $23.0 \mathrm{~mm} / \mathrm{s}$ in floor. Sometimes, it was not possible to record the vibrations simultaneously in the roof, sidewalls and floor.As expected, the vibration amplitudes and frequencies are affected by increasing distance, depth below the surface and geology. Decrease of vibration amplitude with distance on the surface has been well documented in numerous studies [30,27\&17], postulated that an area with abnormal geology would behave differently than its surroundings when exposed to blast vibration.

The geometric spreading has the strongest effect whereas other loss mechanisms such as absorption, dispersion and reflection from existing geological discontinuities influence the vibration amplitude and frequencies significantly.

\section{B. Analyses of recorded vibration data due to open-pit blasting}

Altogether 258 blast vibration data were recorded from 86 blasts. Therecorded vibration data includes; 32 data in roof, 128 data in sidewalls/pillars and 98 data at floor of underground workings. The recorded magnitudes of vibrations (PPVs) at their respective scaled distances are plotted separately for roof, sidewalls/pillars and floor. The maximum vibration recorded in the roof was $24.7 \mathrm{~mm} / \mathrm{s}$ from the blast conducted at open-pit mine with explosive weight per delay of $106 \mathrm{~kg}$ and total explosive weight detonated in the blast round was $28530 \mathrm{~kg}$. The associated dominant frequency was $124 \mathrm{~Hz}$. Monitoring stations were at a radial distance of $149 \mathrm{~m}$. Electronic delay detonators were used as initiation system. In sidewall/pillar, maximum vibration recorded was $35.1 \mathrm{~mm} / \mathrm{s}$ with associated dominant frequency of $166 \mathrm{~Hz}$. The blast was conducted with total explosive weight of $38784 \mathrm{~kg}$ and was fired with pyrotechnic initiation system with explosive weight per delay was $369 \mathrm{~kg}$. The maximum vibration recorded at 


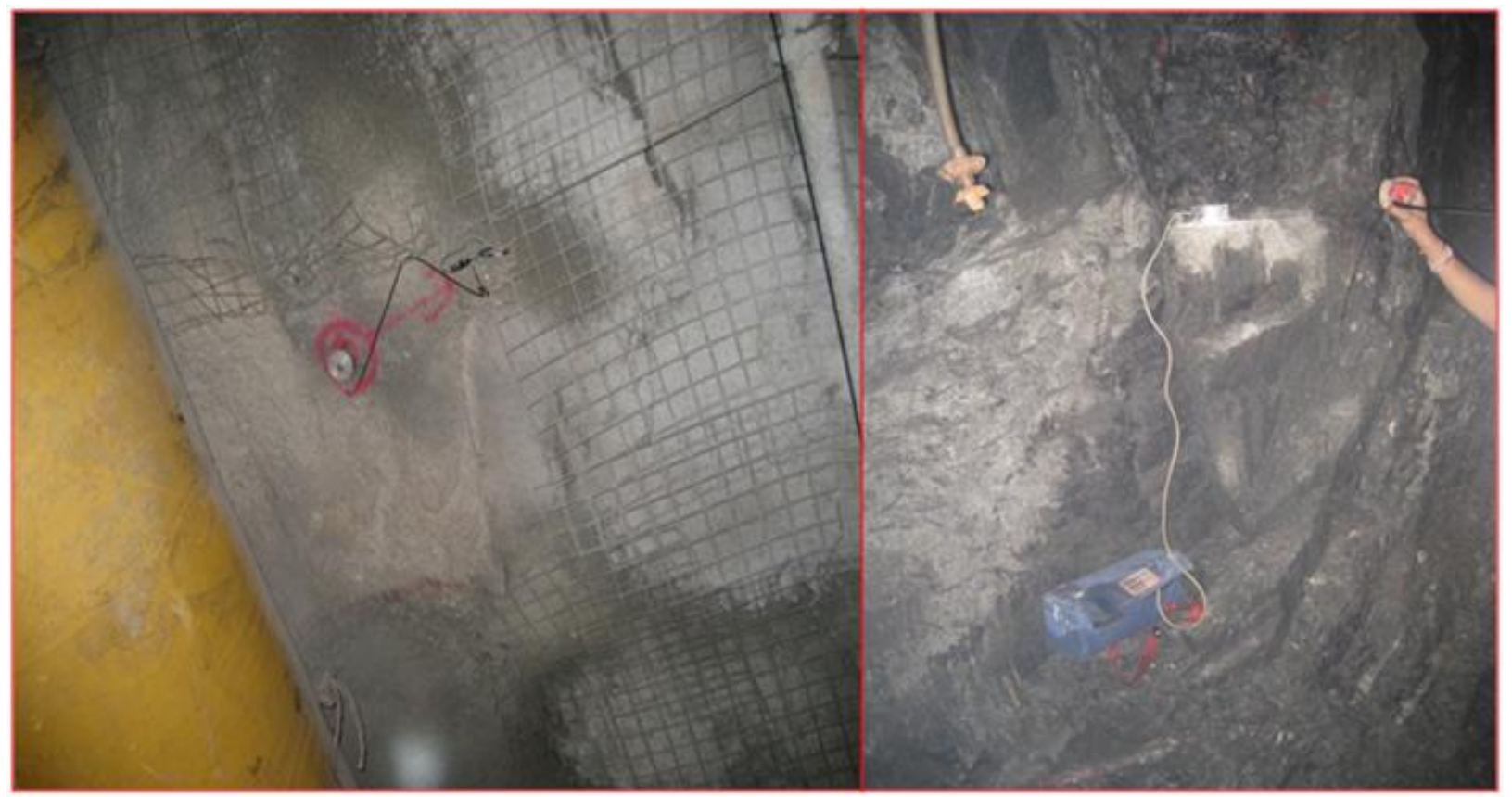

Fig.5. Attachment of geophones of seismographs in the roof and sidewall of underground opening foreground vibration monitoring.

floor was $23 \mathrm{~mm} / \mathrm{s}$ with associated dominant frequency of $164 \mathrm{~Hz}$. The blast was conducted at Ore bench in open-pit mine. Total explosive weight was $34500 \mathrm{~kg}$ andwas detonated with shock tubes (pyrotechnic detonators) with explosive weight per delay was $371 \mathrm{~kg}$. Attempts were made to record the vibration in the underground openings at the closest possible location of open-pit mine blasting side. It was not always possible to record the vibration at a particular location in the roof, sidewall/pillar and floor simultaneously.

There is increased damage potential of low frequency vibration for structure on the surface $[31,34]$. Furthermore, most surface structures have fairly low natural frequency and low frequency vibrations are therefore more likely to produce resonance in the structures and resulting into amplification of vibration. The attenuation of vibration depends mainly on the charge weight, frequency content of wave motion and geotechnical properties of the transmitting medium [27,24,11].The presence of underground voids probably further contributes to the propagation of low frequency vibrations by filtering the higher frequencies in the source functions $[34,36]$, stated that from a theoretical view point, it is not expected that low frequency waves would have any effect on underground workings. In the case of un-weathered rock, the elastic modulus of rock has no obvious influence on the peak frequencies, while in the case of weathered rock, the peak frequency decreases slightly with the decrease of elastic modulus [40].

Dominant frequencies recording underground workings (roof \& sidewall) and on surface due to open pit blasting are plotted together and are presented in Fig.6. It is evident that high frequency vibration data were recorded in underground workings (mainly between 26 to $90 \mathrm{~Hz}$ ) whereas low frequency vibration data were recorded on the surface due to open pit blasting at far off distances from the blasting site. The soil covering and the weathering of the exposed surface rock with discontinuities like joints or fractures have a remarkable influence on the generation of low frequency vibration data whereas in underground, as workings move deeper and deeper, rock mass is more intact and more competent in nature with some geological discontinuities generating high frequency vibration data. However, there were a few exceptions in the recorded frequency data. The blast wave signature recorded on roof and pillar at $200 \mathrm{~m}$ and its Fast Fourier Transform (FFT) analyses is depicted in Fig. 7 and Fig. 8 respectively

The comparative analyses of blast vibration data recorded in underground workings and on the surface due to open pit blasting were grouped separately. The recorded vibration data on the ground surface and in the underground openings in pillars/sidewalls due to open pit blasting have been plotted at various scaled distances Fig.9). It is evident from the figure9 that the vibration recorded on the surface will always be higher than those recorded in the underground openings at similar scaled distances The increase in the level of vibration on the surface to that of underground opening was $42 \%$ higher at scaled distance of 25 . The underground voids must have significant influence on the reduction of ground vibration. The peak particle velocity recorded simultaneously in the roof and pillars/sidewalls of the underground decline due to open-pit blasting are presented in Table II.

Regression analyses of recorded vibration data were performed to derive the propagation equations separately 


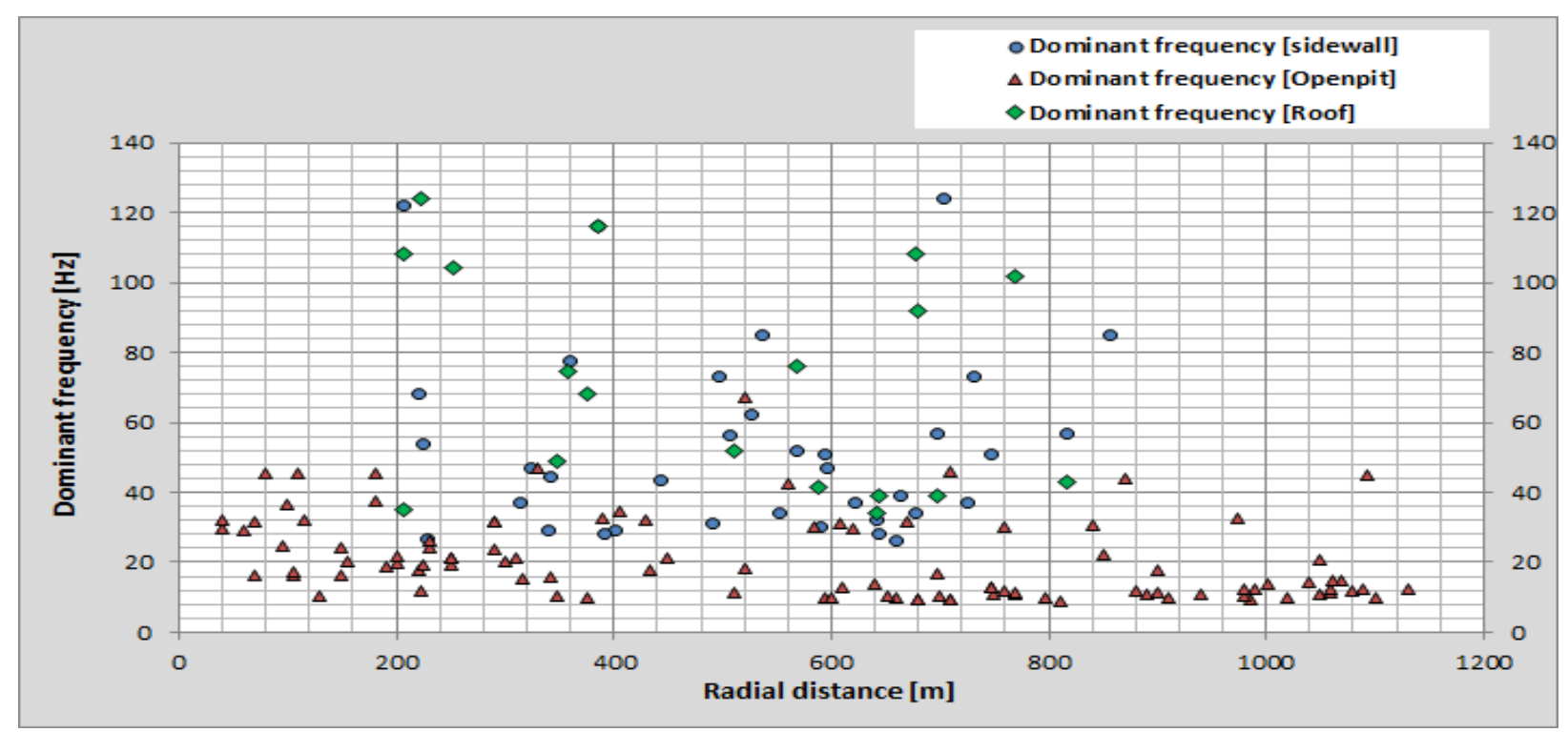

Fig. 6. Plot of recorded dominant peak frequencies monitored on the ground surface and in the underground sidewalls/pillars due to open pit blasting.

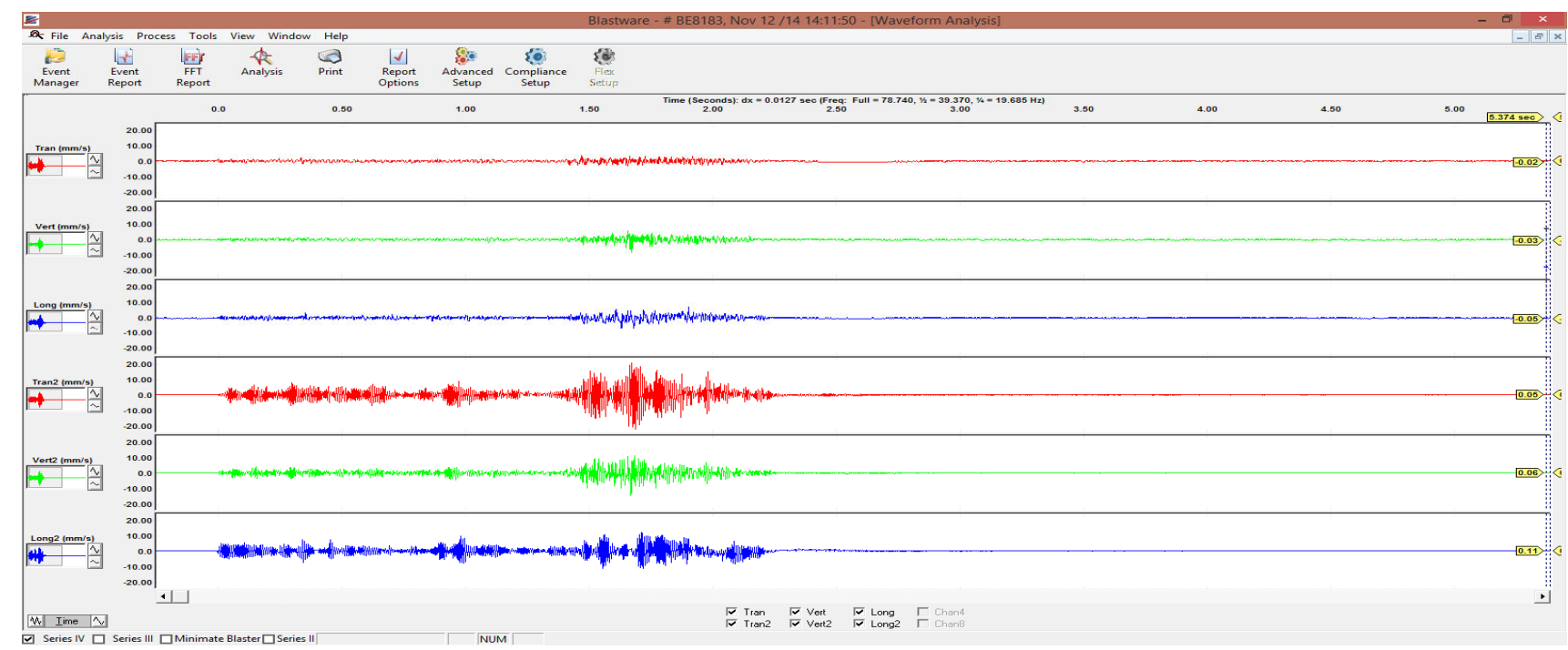

Fig. 7. Blast wave signature recorded on roof and sidewall at a distance of $200 \mathrm{~m}$.

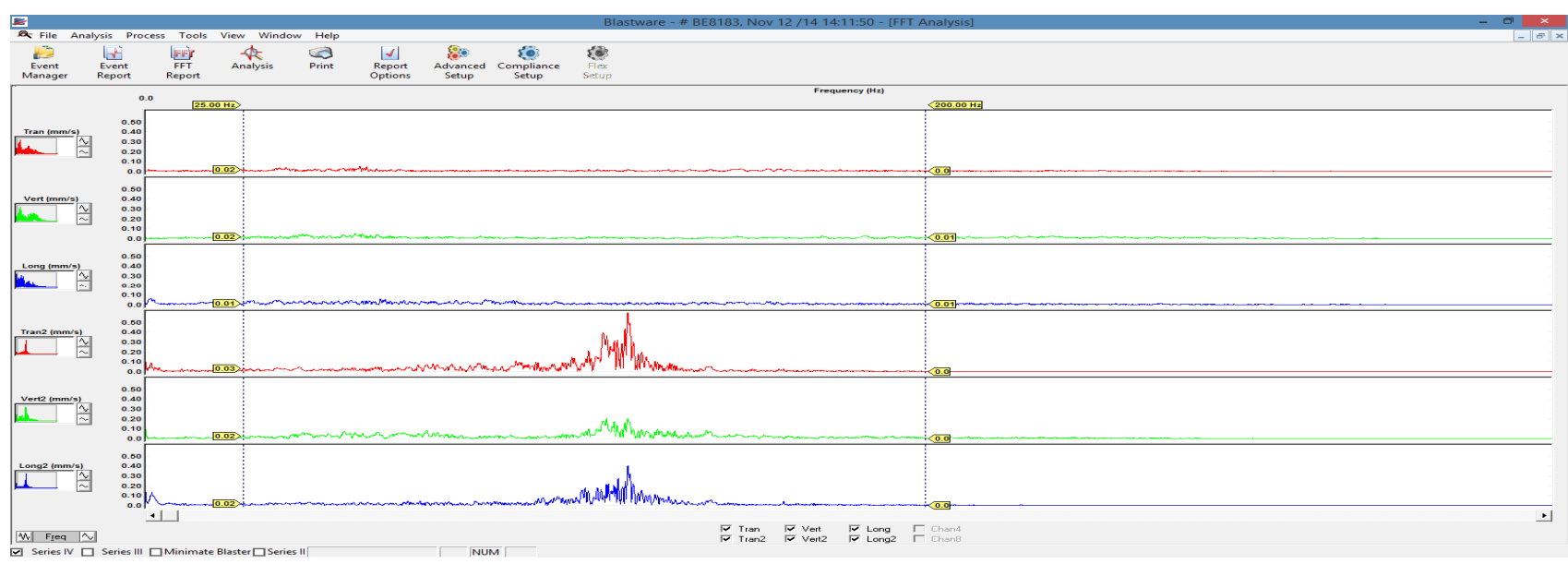

Fig. 8. Fast Fourier Transform (FFT) analyses of frequencies of vibration presented in figure7 
TABLE II .RECORDED BLAST VIBRATION DATA IN THE ROOF AND CORRESPONDING SIDE WALLS/PILLARS DUE TO OPEN-PIT BLASTS IN THE UNDERGROUND OPENING AT RAMPURA AGUCHA UNDERGROUND MINE.

\begin{tabular}{|c|c|c|c|c|c|c|}
\hline $\begin{array}{l}\dot{\mathbf{Z}} \\
\dot{\boldsymbol{n}}\end{array}$ & Location of blast & 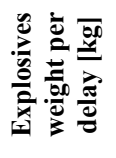 & 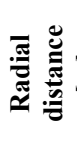 & 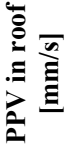 & 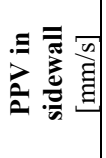 & 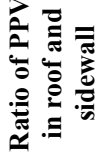 \\
\hline 1. & $\begin{array}{lll}170 / 160 & \text { ORE } & N \\
\text { ALG } & & \\
\end{array}$ & 363 & 817 & 1.01 & 0.637 & 1.6 \\
\hline 2. & $\begin{array}{l}\text { 200/190 H/W N } \\
\text { ALG }\end{array}$ & 440 & 642 & 0.348 & 0.290 & 1.2 \\
\hline 3. & $\begin{array}{lll}180 / 170 & \text { FW } & \text { N } \\
\text { ALG } & & \\
\end{array}$ & 338 & 644 & 0.603 & 0.351 & 1.7 \\
\hline 4. & $\begin{array}{l}200 / 190 \text { ore } \mathrm{S} \\
\text { ALG }\end{array}$ & 276 & 692 & 0.704 & 0.531 & 1.3 \\
\hline 5. & $\begin{array}{lll}170 / 60 & \text { HW } & \text { S } \\
\text { ALG } & & \\
\end{array}$ & 360 & 231 & 5.36 & 2.35 & 2.3 \\
\hline 6. & $\begin{array}{lll}180 / 70 & \text { HW } & \text { S } \\
\text { ALG } & & \\
\end{array}$ & 370 & 228 & 1.6 & 0.842 & 1.9 \\
\hline 7. & $\begin{array}{lll}120 / 10 & \text { FW } & \text { S } \\
\text { ALG } & & \\
\end{array}$ & 194 & 207 & 1.2 & 0.421 & 2.8 \\
\hline 8. & $\begin{array}{lll}170 / 60 & \text { HW } & \text { S } \\
\text { ALG } & & \\
\end{array}$ & 360 & 385 & 5.36 & 2.35 & 2.28 \\
\hline 9. & $\begin{array}{lll}180 / 70 & \text { HW } & \text { S } \\
\text { ALG } & & \\
\end{array}$ & 370 & 228 & 1.6 & 0.842 & 1.9 \\
\hline 10. & $\begin{array}{lll}140 / 30 \quad \text { HW } & \text { S } \\
\text { ALG TRIM }\end{array}$ & 304 & 526 & 1.79 & 0.475 & 3.76 \\
\hline
\end{tabular}

for roof, pillar and floor. The scaled distance concept is used for blast vibration prediction and is defined as the actual distance $(R)$ of the vibration measuring point from blasting face divided by square root of the maximum explosives weight per delay $\left(Q_{\max }\right)$ as per the USBM predictor model. The predictor equations derived at $95 \%$ confidence level along with their correlation coefficients are presented in Table 3. The table also contains other data such as ranges of recorded PPV, frequency, maximum explosive weight per delay and the distance of recording vibration etc. Propagation equation at $95 \%$ confidence level invariably is being used to design a blast to contain blast induced vibration within the threshold limits.
This will ensure the safety of the underground workings from vibration generated due to open pit blasting. Figure10 depicts the regression plot of recorded blast vibration data for roof and pillars/sidewalls at $95 \%$ line equation. The regression analyses of the vibration data recorded in roof and pillars/sidewalls are illustrated graphically in Fig. 11.

TABLE III. RECOMMENDED PROPAGATION EQUATIONS FOR PREDICTION OF BLAST INDUCED VIBRATION AT RAMPURA AGUCHA UNDERGROUND OPENINGS DUE TO OPEN-PIT BLASTING.

\begin{tabular}{|c|c|c|c|c|c|c|}
\hline 章 & 矛 & 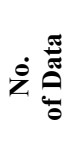 & 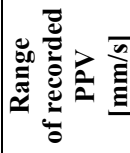 & 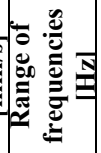 & 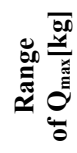 & 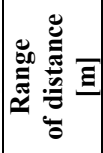 \\
\hline Roof & $\begin{array}{c}\left.V=3.32 .5 I^{R} /_{\sqrt{ } U_{\max }}\right]^{-1.6} \\
\text { Correlation } \\
\text { coefficient }-76.8 \%\end{array}$ & 32 & $\begin{array}{l}0.439 \\
-24.7\end{array}$ & $\begin{array}{l}34- \\
240\end{array}$ & $\begin{array}{l}30- \\
516\end{array}$ & $\begin{array}{l}207- \\
1073\end{array}$ \\
\hline Pillar & $\begin{array}{c}F=1043\left[^{R} /_{\sqrt{ } Q_{\max }}\right]^{-1.4 p} \\
\text { Correlation } \\
\text { coefficient }-73.0 \%\end{array}$ & 138 & $\begin{array}{c}0.46 \\
-35.1\end{array}$ & $\begin{array}{c}13.9- \\
247\end{array}$ & $\begin{array}{l}28- \\
825\end{array}$ & $\begin{array}{c}98- \\
2014\end{array}$ \\
\hline Floor & $\begin{array}{c}F=332\left[\left[^{R} E_{\xi} Q_{\max }\right]^{-1 / 2}\right. \\
\text { Correlation } \\
\text { coefficient }-74.2 \%\end{array}$ & 88 & $\begin{array}{c}0.42- \\
23.0\end{array}$ & $\begin{array}{c}16.6- \\
249\end{array}$ & $\begin{array}{l}54- \\
825\end{array}$ & $\begin{array}{c}97- \\
2171\end{array}$ \\
\hline
\end{tabular}

[22] witnessed that the Nonel initiation (pyrotechnic detonators) results in longer cracks and also produce rougher remaining rock surface and frequently undetonated charges found in the muck pile which suggest the prominent misfire.The computation of ground vibrations generated from pyrotechnic and electronic initiation systems were performed and it is observed that there is 8 to $10 \%$ reduction in ground vibration in case of electronic initiation system in comparison to pyrotechnic initiation device. It was suggested that any blast within a radial distance of $100 \mathrm{~m}$ must be conducted using Electronic initiation system to minimize blast induced ground vibration

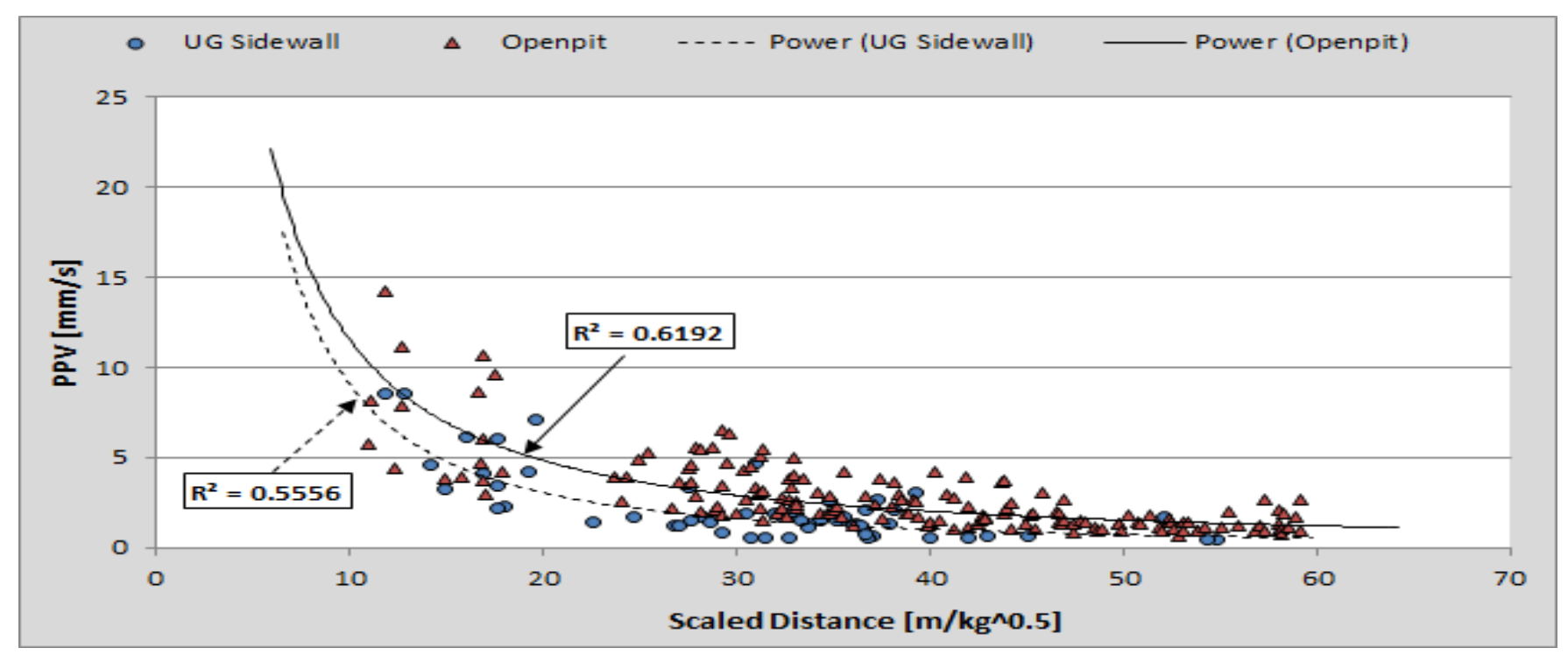

Fig. 9.Plot of recorded peak particle velocity on the ground surface and in the pillars of underground openings due to open pit blasting 


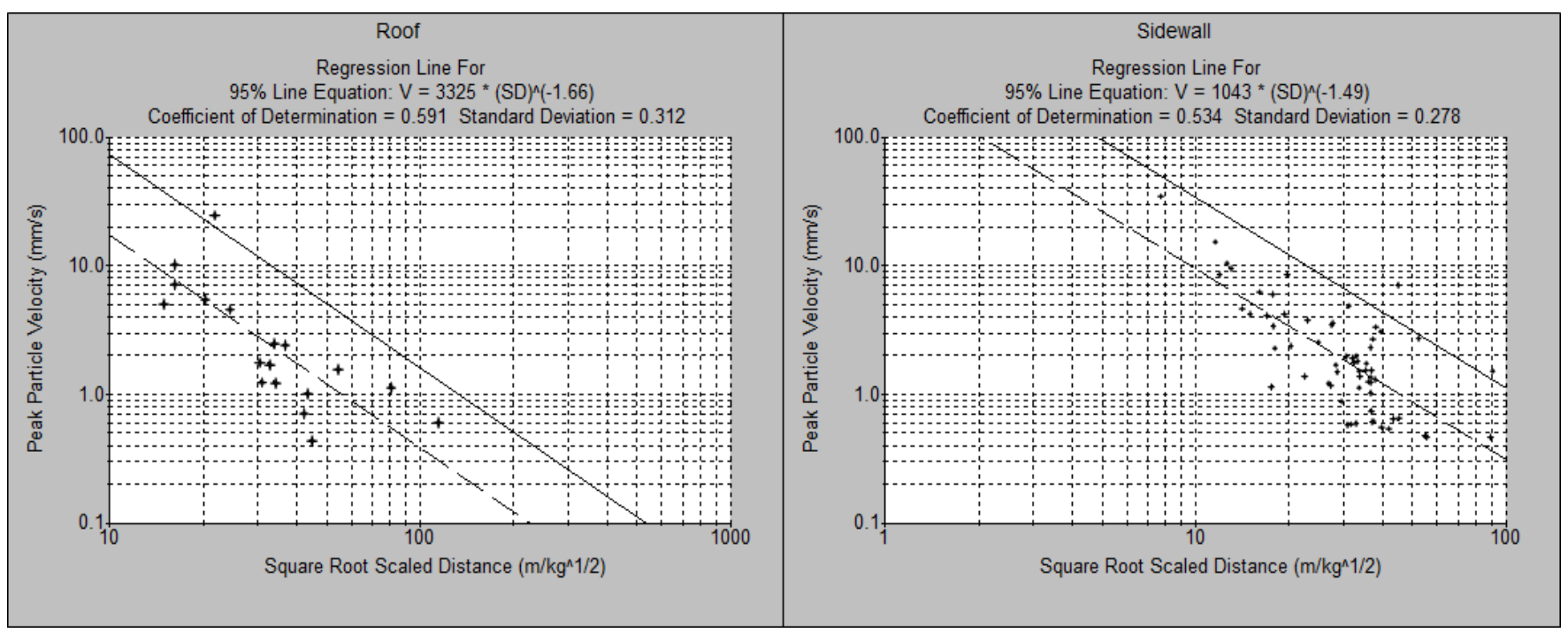

Fig. 10. Regression plot of recorded blast vibration data in roof and sidewalls at $95 \%$ line equation.

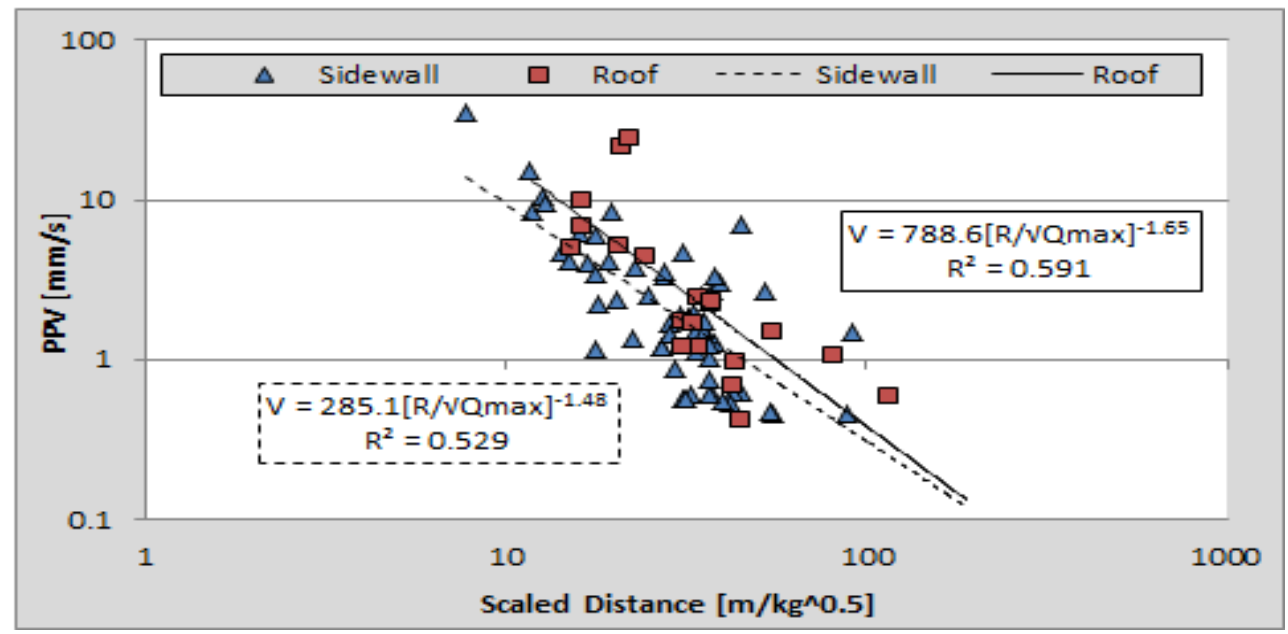

Fig. 11. Propagation plots of peak particle velocity as a function of scaled distance for the data recorded in roof and pillars/sidewalls

in the underground openings. The established propagation equation for both initiation systems is depicted in Fig.12.Computed maximum explosive weight per delay for recommended threshold values of ground vibration for the safety and stability of underground openings in sidewalls on the basis of pyrotechnic detonator and electronic detonator is depicted in table 4. A comparative propagation equation of PPV data recorded at underground and surface monitoring locations from the same blast were plotted Fig 13). It is evident from the figure that there is significant decrease in PPV values in underground compared to surface monitoring locations.

\section{UNDERGROUND BLAST RESULTS AND ANALYSES}

Blast induced ground vibration generated in underground openings due to development face and production blasts were also recorded and analyzed for the safety of the underground workings. The installation of geophone on the roof is a tedious job in underground workings as the development faces advances rapidly
TABLE IV. THRESHOLD VALUES OF VIBRATION FOR THE SAFETY OF ROOF, PILLARS/SIDEWALLS IN BELOW GROUND WORKINGS FOR DIFFERENT RMR DUE TO ADJACENT OPEN-PIT BLASTING.

\begin{tabular}{|c|c|c|}
\hline $\begin{array}{c}\text { RMR of roof } \\
\text { rock }\end{array}$ & $\begin{array}{c}\text { Threshold value of } \\
\text { vibration in terms of } \\
\text { peak particle velocity } \\
\text { for the safety and } \\
\text { stability of roof } \\
{[\mathbf{m m} / \mathbf{s}]}\end{array}$ & $\begin{array}{c}\text { Threshold value of } \\
\text { vibration in terms of } \\
\text { peak particle velocity } \\
\text { for safety and stability } \\
\text { of pillars/sidewalls } \\
\text { [mm/s] }\end{array}$ \\
\hline $20-30$ & 50 & 20 \\
\hline $30-40$ & $50-70$ & $20-30$ \\
\hline $40-50$ & $70-100$ & $30-40$ \\
\hline $50-60$ & $100-120$ & $40-50$ \\
\hline $60-80$ & 120 & 50 \\
\hline
\end{tabular}

therefore the generation of near field vibration data were difficult to record. Attempts were made to collect maximum data possible from sidewall notched prepared and in absence of notches on the floor.Initially, ground vibrations from the existing blast design patterns were recorded and analyzed. Based on the observations and relevant supporting 
documents of actual delay detonation of initial five holes of development face, it was concluded that after detonation of $11^{\text {st }}$ centre hole, the immediate surrounding four holes detonated instantaneously (Fig 14A). The development face blast design patterns were modified and ground vibrations were monitored for further analyses (Fig 14B). In total, 49 blasts were conducted including 44 development face blasts and 5 production blasts. In production blasts the total explosive detonated were in the range of $300 \mathrm{~kg}$ to $2459 \mathrm{~kg}$ whereas in development face blast, it was in the range of $210 \mathrm{~kg}$ to $350 \mathrm{~kg}$. The radial distance of ground vibration monitoring locations lies in between $20 \mathrm{~m}$ and $950 \mathrm{~m}$. The PPVs recorded due to underground blasting ranges between $0.651 \mathrm{~mm} / \mathrm{s}$ and $75.5 \mathrm{~mm} / \mathrm{s}$. The maximum PPV recorded from the production blast was $75.5 \mathrm{~mm} / \mathrm{s}$ in sidewall with dominant peak frequency of $148 \mathrm{~Hz}$ at $59 \mathrm{~m}$.
The total explosive weight and explosive weight per delay used in this blast was $2459 \mathrm{~kg}$ and $157 \mathrm{~kg}$ respectively. The PPVs data were grouped together for statistical analyses and propagation equation for roof, sidewall and floor were derived Fig 15.

\section{THRESHOLD VALUE OF VIBRATION FOR THE SAFETY OF ADJOINING UNDERGROUND WORKINGS}

The peak particle velocityhas traditionally been used as a criteria to establish the degree of blast damage[14,3,42,10 \&21].The rock damage extent around the underground workings linearly increases with the peak particle velocity $[39,18]$. Additionally, the mining industry is quite familiar with PPV and its relative ease of measurement has generally formed the basis of blast damage criteria for underground

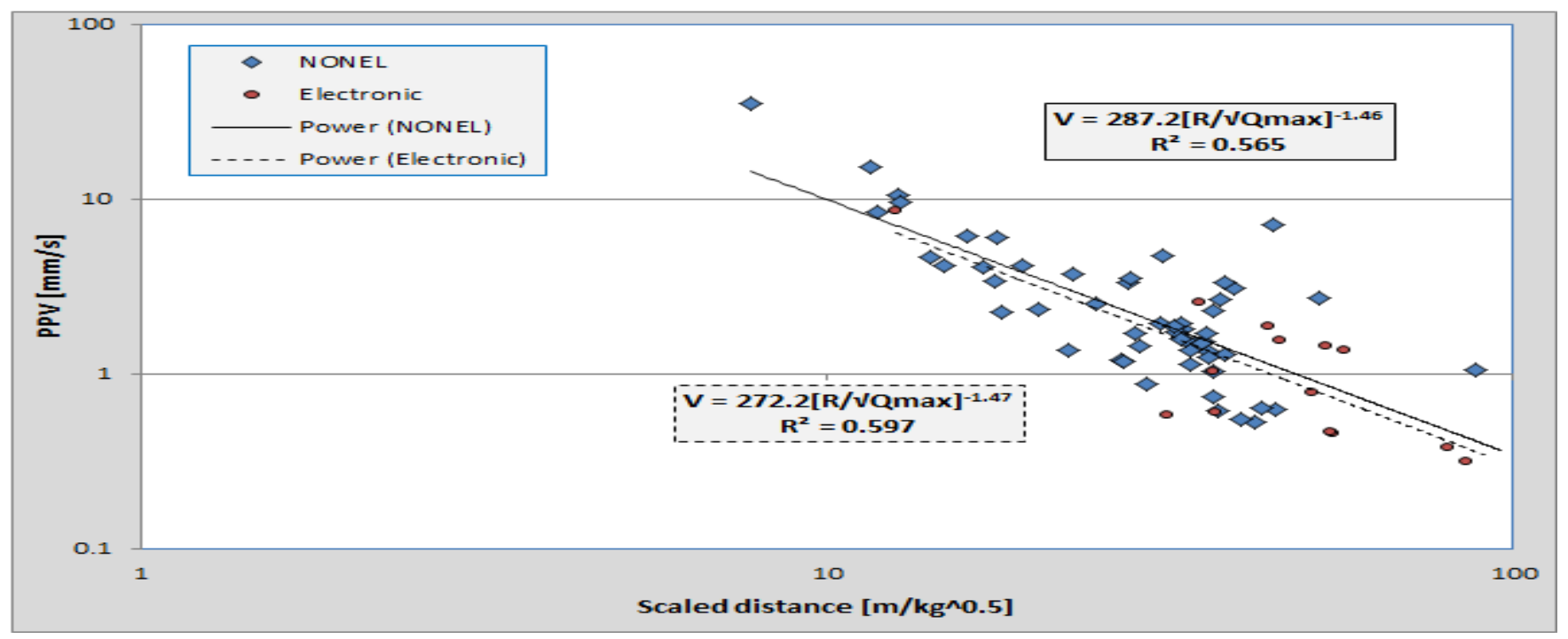

Fig. 12. Plot of recorded vibration data due to Pyrotechnic and electronic initiation devices

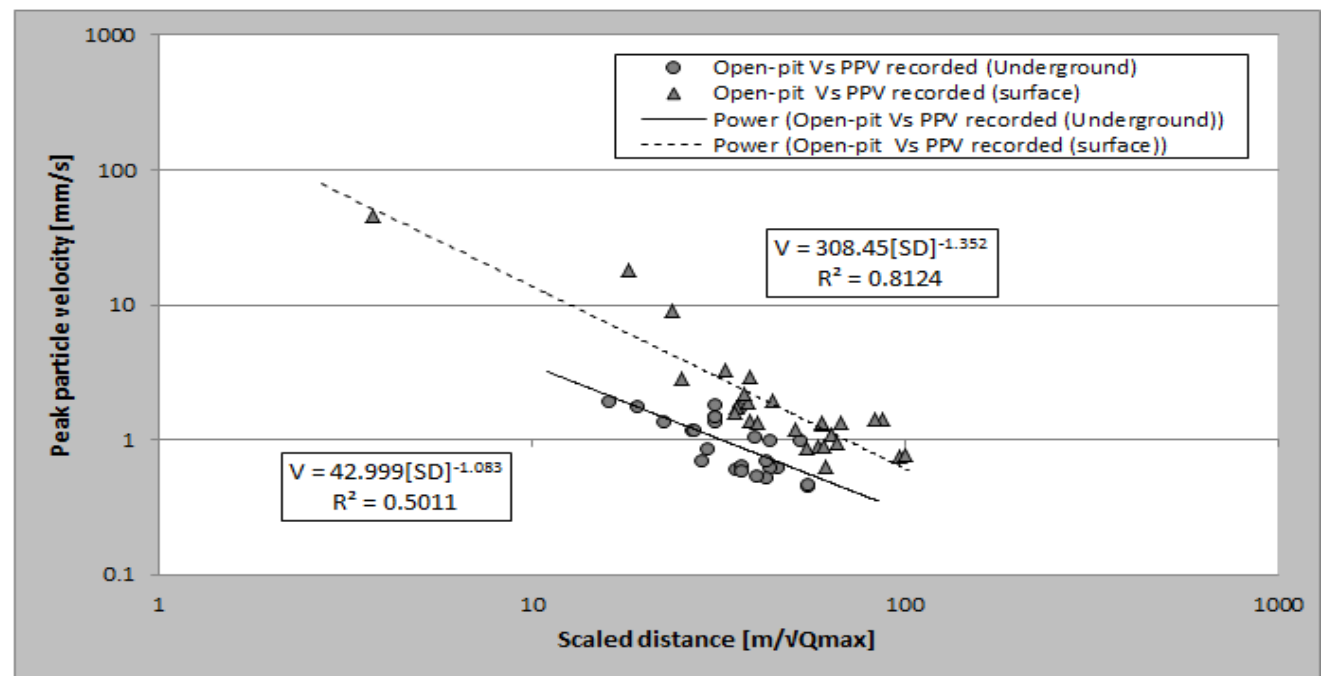

Fig. 13. Plot of recorded vibration data simultaneously at different scaled distances due to open-pit blasts at ground surface and in underground openings. 

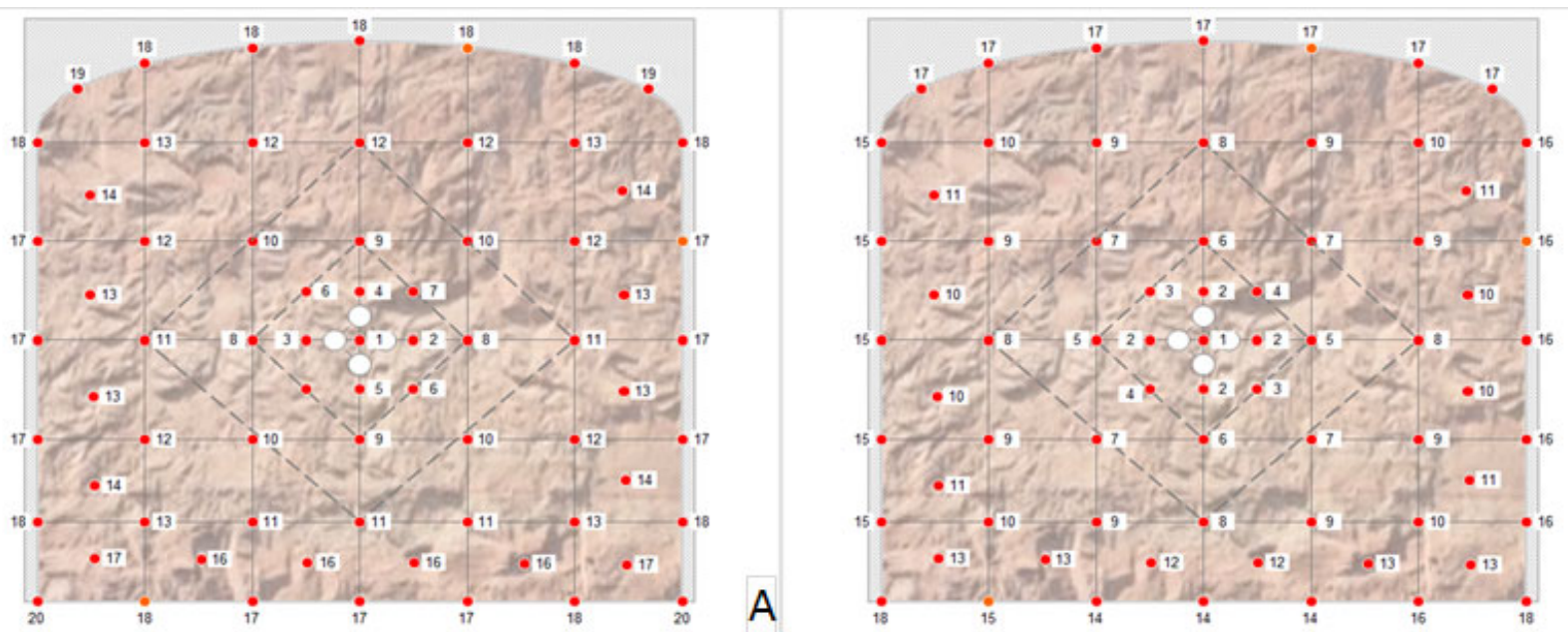

Fig. 14. Development face blast designs used at Rampura Agucha underground mine. [A] Existing blast design pattern; [B]Recommended blast design pattern.

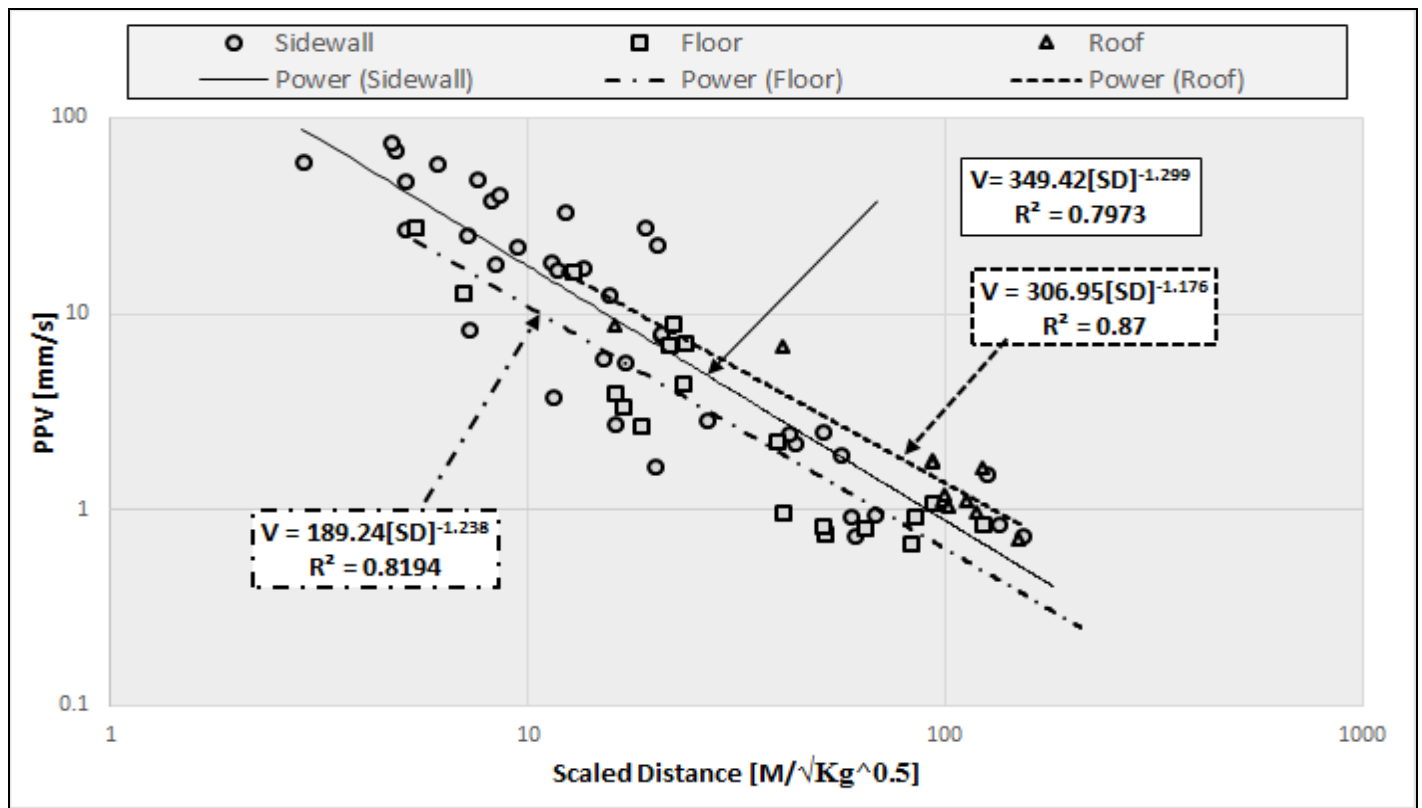

Fig. 15. Plots of recorded peak particle velocity at different scaled distance $\left[\mathrm{SD}=\right.$ Distance $\left./ \sqrt{ } \mathrm{Q}_{\max }\right]$ for the data recorded in roof, sidewalls and floor due to development and production blasts of Rampura Agucha underground mine

excavations [2]. Many observations, however, have shown that damage to the underground workings varies from one location to another depending on the site characteristics [5, $20,33,38]$, observed that tunnel excavated in poor quality rock with loose or open jointing suffers more damage than tunnels mined in good quality rock when subjected to a given level of ground vibration.

The RMR classification system, [5] was developed for characterising the rock mass and for providing a design tool for tunneling with greater safety. Visual inspections of underground workings were carried out after each of the blasts. no damage was observed in the underground workings during the study period.The degree of damage observed in the belowground openings is influenced by the RMR of roof rock. Thus, the damage criterions for below ground workings are based on RMR as reported by [27], and are given in Table. IV.

The Rock Mass Rating (RMR) values of the vibration monitoring locations ranges from 50 to 72 . Thus, the threshold valuesof PPVs for roof and for corresponding pillar/sidewall are $100 \mathrm{~mm} / \mathrm{s}$ and $40 \mathrm{~mm} / \mathrm{s}$ respectively by taking the lower values of RMR of 50 . The average ratio of ground vibration in terms of peak particle velocity in sidewall/pillars to floor is $2: 1$ [27]. Based on this data, the threshold value of vibration for floor is considered as 20 $\mathrm{mm} / \mathrm{s}$. The computedmaximum explosive weight per delay for open-pit blasting to maintain the threshold value of ground vibration in the underground pillars/sidewalls is presented in Table $\mathrm{V}$, which also contains the maximum explosive weight per delay to be detonated in underground 
development face blasting to maintain the threshold level of vibration in sidewalls/pillars. Blast designs for open-pit mine were optimized which resulted into lower level of vibration in the underground openings. The monitoring of vibration in the sidewalls is more feasible for each blast and accordingly the predicted maximum explosives weight per delay in open-pit blast as well as underground blasts has been standardized so that vibration experienced by the underground openings must be well within safe limits and long term safety of the underground mine opening may be ensured.

TABLE V .COMPUTED MAXIMUM EXPLOSIVE WEIGHT PER DELAY FOR RECOMMENDED THRESHOLD VALUES OF GROUND VIBRATION FOR THE SAFETY AND STABILITY OF UNDERGROUND OPENINGS IN SIDEWALLS.

\begin{tabular}{|c|c|c|}
\hline \multirow{2}{*}{$\begin{array}{c}\text { Radial } \\
\text { distance }\end{array}$} & \multicolumn{2}{|c|}{ Explosive weight per delay [kg] } \\
\cline { 2 - 3 }$[\mathbf{m}]$ & $\begin{array}{c}\text { Threshold value of } \\
\text { vibration of 40 mm/s in } \\
\text { pillars/sidewalls due to } \\
\text { open-pit blasts }\end{array}$ & $\begin{array}{c}\text { Threshold value of } \\
\text { vibration of 40 } \mathbf{~ m m} / \mathbf{s} \text { in } \\
\text { pillars/sidewals due to } \\
\text { underground blasts }\end{array}$ \\
\hline 50 & 176 & 113 \\
\hline 60 & 254 & 163 \\
\hline 70 & 345 & 222 \\
\hline 80 & 451 & 290 \\
\hline 90 & 571 & 367 \\
\hline 100 & 705 & 453 \\
\hline 125 & 1101 & 707 \\
\hline 150 & 1586 & 1019 \\
\hline
\end{tabular}

\section{CONCLUSIONS}

The blast induced ground vibration data generated from Pyrotechnic and Electronic initiation system were analyzed separately. The results revealed that Electronic initiation system produced 8 to $10 \%$ lower level of vibration in comparison to Pyrotechnic initiation system in underground openings. It isrecommended that if anopen-pit blast is to be conductedat 100 mor further close (i.e. up to $60 \mathrm{~m}$ ) from underground openings, the blast should be initiated withElectronic delay detonators for enhanced safety to the adjacent underground openings.

The comparative analyses of peak particle velocities recorded on surface and in underground openings due to open-pit blasting shows that the vibration recorded in the underground openings were much lower than those recorded on the ground surface for the same scaled distances. It is found that alongwith the geometrical spreading, the underground voids plays important role in attenuation of ground vibration. Thereduction in blast vibration was up to $42 \%$ in comparison to those recorded on the surface at a scaled distance of 25 . High frequency ground vibration data wererecorded in underground openings whereas on ground surface low frequency ground vibration data were monitored due to open-pit blasting.

The Rock Mass Rating (RMR) values of the underground vibration monitoring locations varied from 50 to 72 . Therefore, the threshold values of vibration for the safety of underground roof, pillars/sidewalls and floor would be $100 \mathrm{~mm} / \mathrm{s}, 40 \mathrm{~mm} / \mathrm{s}$ and $20 \mathrm{~mm} / \mathrm{s}$ respectively. These threshold values of PPVs were taken for lower values of RMR i.e. 50 for the greater safety of the underground workings. Blast designs has been standardized for open-pit blasting as well as underground development and ring hole blastingand accordingly both the mines are producing minerals with enhanced safety and stability to the underground structures.

\section{ACKNOWLEDGEMENTS}

The author expresses his thankfulness to the mine officials for providing necessary facilities during field investigations. The support of the research team of CSIRCentral Institute of Mining and Fuel Research, Dhanbad, India in field studies is thankfully acknowledged.

\section{REFERENCES}

[1] Andieux P, Mckenzie C, Heilig J,Drolet A.The impact of blasting on excavation design - A geomechanicsapproach. InProc. $10^{\text {th }}$ AnuSympExpBls Res.International Society of Explosives Engineers: Austin. Tx: January 30 to February 4 1994. p. 107-119.

[2] Atlas power Company, 1987. Explosives and Rock Blasting. Dallas, Texas, USA; p. 662.

[3] Bauer A, Calder P. Open pit and blast seminar.Course note, Queen's University, Kingston, Ontario; 1978.

[4] Bawden WF, Katasbanis P, Yang RL, 1993. Blast damage study by measurement and numerical modeling of blast damage and vibration in the area adjacent to blast hole. InProcInt Cong Min Design, Kingston, Canada, 1993, p. 853-861.

[5] Bieniawski ZT, 1989. Engineering rock mass classifications: a complete manual for engineers and geologists in mining, civil, and petroleum engineering. Wiley-Interscience. pp. 40-47.

[6] Fadeev AB, Glosman LM,Sofonov LV. Seismic control of mine and quarry blasting in the USSR. InProcInt Cong Rock Mech. ISRM: Montreal, Canada;1987 6:17-619.

[7] Fourie AB, Green RW.Damage to underground coal mines caused by surface blasting.IntJ Sur Min 1993; 7:11-16.

[8] Gu R,Ozbay U. Distinct element analysis of unstable shear failure of rock discontinuities in underground mining conditions.Int J Rock Mech Min Sci2014; 68:44-54.

[9] Heron AM. The geology of Central Rajputana: Memoir geological Survey of India. 1953, Vol.59, p. 389.

[10] Holmberg R, 1982. Charge calculations for tunnelling.InUnderground Mining Methods Handbook. Ed: W A Hustrulid,Society for Mining, Metallurgy and Exploration; 1982, p. 1580-1589.

[11] Hustrulid W. Blasting Principles for Open pit Mining. Volume 1, A. A. Balkema.Pub; 1999,p. 382.

[12] Jensen DE, Munson RD,Oriard LL, Reitman JD, Wright RS.Underground vibration from surface blasting atJenny mine, KY. Woodward-clydeconsultants, Orange CA. Final contract RPT. J0275030 for the USBM, November 1979, p. 99.

[13] Kidybinski A. Design criteria for roadway supports to resist dynamic loads.Int J Min GeolEng 1986; 4:91-109.

[14] Langefors U, Kihlstrom B, 1963. The modern technique of rock blasting, John Wiley and Sons.Inc; New York; 1963, p. 265-295.

[15] Lewandowski T, Keith G,Croucher M, Richards A.The impact of surface blasting on underground opening-geotechnical assessment.InProc of $6^{\text {th }}$ IntSymp Rock FragBls.Fragblast6. Johannesburg, South Africa: 8-12 August 1999.p.131-138.

[16]Lewandowski T, Kelly P, Weeks G. Developing a Blast Management Plan for Open Cut Coal Mine Adjacent to an Underground Colliery.In Proc $8^{\text {th }}$ IntSymp Rock Frag Bls. Fragblast 8. Santiago, Chile: May, 2006. p. 375-382.

[17] Lewandowski T, Richards L, Hamson L, Merchant M, Spargo A. The Impact of geological fractures on level of ground vibrations.In proc $9^{\text {th }}$ IntSymp Rock Frag Bls.Fragblast 9. Granada, Spain: September 13-17, 2009. p. 535-543. 
[18]Li JC, Li HB, Ma GW,Zhou YX, 2013. Assessment of underground tunnel stability to adjacent tunnel explosion.Tunnel Ug Space Tech 2013; 35: 227-234.

[19] Masui A,Sen GC.Underground vibrations from adjacent open cut blasts.Joint MMIJ/AusIMM Conference: New Horizons in Resources Handling and Geo-engineering, Ube, Japan;1994. p. 361-367.

[20] Morhard RC, Chiappetta RF, Borg DG, Sterner VA. Explosives and rock blasting.Atlas Powder Company, 1987, p. 159-203,p. 330-350, p. 662.

[21] Oriard LL. Blasting effects and their control.In Underground Mining Methods Handbook. Ed: W A Hustrulid, Society for Mining, Metallurgy and Exploration; 1982, p. 1590-1603.

[22] Ouchterlony F, Olsson M, Svard J. Crack lengths or blast damage from string emulsion and electronic detonators. In Proc ${ }^{\text {th }}$ IntSymp Rock Frag by Bls. Fragblast 9, Granada, Spain, September 13-17, 2009, p. 469-480.

[23] Ouchterlony F, Sjöberg C,Jonsson BA.Blast damage predictions from vibration measurements at the SKB underground laboratories at Äspö in Sweden. In Proc 9th Annual SympExpl and Bls Res. Cleveland OH: ISEE, 1993,p. 189-197.

[24]Persson P, Holmberg R, Lee J. Rock Blasting and Explosives Engineering. CRC Press, Inc;1994, p. 540.

[25] Rossmanith HP. The Mechanics of Spalling in Rock Reconsideration.In Proc $8^{\text {th }}$ IntSymp Rock Frag Bls.Fragblast 8 . Santiago, Chile: May, 2006. p. 99-103.

[26] Rupert GB, Clark CB.Criteria for the proximity of surface blasting to underground coal mines. In Proc $18^{\text {th }}$ symp Rock Mech.Keystone (Colorado School of Mines), 1977; 3C 3 :1-10.

[27] Singh PK. Blast vibration damage to underground coal mines from adjacent open-pit blasting. IntJ Rock Mech Min Sci 2002; 39(8):959973

[28] Singh PK, Roy MP. 2010. Damage to surface structures due to blast vibration. Int J of Rock Mech and Min Sci2010; 47(6): 949-961.

[29] Singh PK, Singh RB, Singh, TN, Singh, DP. Impact of surface blasting on the stability of underground workings.In Proc $6^{\text {th }}$ IntSymp Rock Frag Bls.Fragblast 6. South African Institute of Mining and Metallurgy: 8 - 12 August 1999. p. 139 - 144.

[30] Singh PK, Vogt W, Singh RB, Singh MM, Singh DP. Response of surface structures to rock blasting. Mineral Res Eng, UK, 1997; 6(4): 185-194.

[31] Singh PK. A study on ground vibrations due to rock blasting. Ph.D thesis publishedbyPapierlieger, ISBN 3-89720-106-2, ClausthalZellerfeld, Germany, 1998, p. 210.

[32] Singh RB, Singh PK, Prakash AJ,Dhar BB. Stability of underground coal mine openings and structures with particular reference to vibrations from surface mine blasts. Int EXPLO'95 Con, Brisbane, Australia: 4-7 September 1995. p. 329-332.

[33] Singh SP. Investigation of blast damage mechanism in underground mines.Report to MRD Mining Research Directorate, Sudbury, 1992, p. 50 .

[34] Siskind DE, Stachura VJ,Nutting MJ. Low-Frequency Vibrations Produced by Surface Mine Blasting Over Abandoned Underground Mines. U S Bureau of Mines RI 9078, 1987, p. 58.

[35] Siskind DE, Stagg MS, Kopp JW, Dowding CH. Structure response and damage produced by ground vibration from surface mine blasting. Report of investigation 8705 US Bureau of Mines, 1980.

[36] Siskind DE. Blast vibration damage to underground mines and unlined tunnels, A survey and summary review. DESA, 1997, p. 10.

[37] Stacey TR, Cameron-Clarke IS, Mival K. Stabilisation of old coal mine blasting: Case study of a failed experiment. Static and dynamic considerations in rock surface blasting. Int J Sur Min 1990; 7(1): 1116.

[38] Tunstall AM.Damage to underground excavations from open-pit blasting.Inst Min and Met (Sect. A: Min. industry) 1997; 106: A19A24.

[39] Xia X, Li JC, Liu B, Yu C.A case study on rock damage prediction and control method for underground tunnels subjected to adjacent blasting.Tunnel Ug Space Tech2013; 35: 1-7.
[40] Yang G, Jiang Y, Li B, 2014b, Estimation of effect of voids on frequency response of mountain tunnel lining based on microtremormethod.Tunnel Ug Space Tech 2014b; 42:184-194.

[41] Yang HQ, Zeng YY, Lan YF, Zhou XP. Analysis of the excavation damaged zone around a tunnel accounting for geo-stress and unloading.Int J Rock Mech Min Sci 2014a; 69:59-66.

[42] Yu TR. Ground control at Kidd Creek Mine in Underground Rock Engineering.Inproc $13^{\text {th }}$ Canadian Rock Mechsymp1980; 73-79. 